都市鉄道利用者を対象とした出発時刻選択モデルの選択肢設定に関する基礎的考察* Comparative analysis of choice set for commuting time of day choice model in urban railway networks*

岩倉成志**・原田知可子***•鈴木修司 $* * * *$

By Seiji IWAKURA** - Chikako HARADA*** - Shuuji SUZUKI****

1. はじめに

東京圈の都市鉄道は, ピーク時の非常に高い混雑率に 加えて, 列車速度の低下という相乗的なサ一ビス悪化が 問題となっている. 輸送力の増強によるサービス改善が 必要であるが, 供給側の対策のみでの混雑緩和は困難で あり，フレックスタイム制度や時間差料金制度など，需 要側の利用時間分散策の推進が必要と言える.

こうした政策の需要変動を事前に分析するためには, 時刻別の需要予測手法が必要である，筆者ら ${ }^{11}$ は, RPとS $\mathrm{P}$ 融合した出発時刻選択モデル，就業制度や始業時刻 によって異なる出発時刻の選択肢集合の選別モデルを構 築し，ピークロードプライシングやフレックスタイム制 度の効果計測を可能にした.

ここで作成した出発時刻選択モデルは，選択肢区分を アプリオリに30分間隔の8肢選択モデルとした. 一方で, 家田ら 2 は選択肢区分を10分間隔とする36肢選択モデル を構筑している. 選把肢区分を細かくすることによって, 出発時刻の選択行動を詳細に記述できるが，パラメータ の安定性が低下したり, 尤度比が低下する恐れがある. 選択肢区分の粗密がパラメータやモデルの精度に与える 影響に関する知見は数少ない，また，出発時刻選択モデ ルの選択肢間の類似性についての指摘34)がなされており, その点でも選択肢区分の設定方法に関する知見の蓄積は 重要な課題と考える.

そこで本研究では，選択肢区分の設定を変更した場合 のモデルの再現精度, パラメータ感度の変化, 選択肢間 の誤差相関に関する実証分析を試みる，具体的には，東 京圈の都市鉄道である東海道線戸塚駅, 小田急小田原線 新百合ヶ丘駅の周辺に居住し, 東京都心向う通勤者を 対象に，自宅出発時刻のRPデータをアンケート調査によ って取得する. 非集計ロジットモデルによって出発時刻 選択モデルを構築するが, その際15分ピッチ，30分ピッ チ，60分ピッチの選択肢区分でモデルを構築し，モデル

*キーワーズ : TDM, 交通行動分析, 公共交通運用

**正員, 工博, 芝浦工業大学工学部土木工学科

（干108-8548 東京都港区芝浦3-9-14,

TEL03-5476-3049, FAX03-5476-3166)

***学生員, 芝浦工業大学大学院建設工学専攻

$* * * *$ 非会員, 川崎市役所
表 1. 調查概要

\begin{tabular}{|c|c|c|c|}
\hline 対象駅 & $\begin{array}{c}\text { (1)JR東海道線 } \\
\text { 戸塚駅 }\end{array}$ & $\begin{array}{l}\text { (2)小田急小田原線 } \\
\text { 新百合ヶ丘駅 }\end{array}$ & \\
\hline \multicolumn{4}{|c|}{ 対象駅を利用する通勤者へのはがきアンケート調査 } \\
\hline 配布場所 & \multicolumn{3}{|c|}{ 駅周辺及びバス停 } \\
\hline 配布枚数 & 2499 枚 & 2435 枚 & 計4934枚 \\
\hline 配布日 & 6(火) & 13(火) & $17: 00$ \\
\hline (2002年11月) & 7 (水) $) \cdot 8$ (木) & 14 (水) & $5: 30 \sim 9: 30$ \\
\hline 回収枚数 & 718 枚 $(28.7 \%)$ & 816 枚 $(33.6 \%)$ & 計 1534 枚 $(31.1 \%)$ \\
\hline 調査内容 & \multicolumn{3}{|c|}{$\begin{array}{l}\text { 家を出る時刻, 出発可能な時間幅, アクセス手段, 鉄道経 } \\
\text { 路, 出発時刻決定要因, 業務形態, 個人属性など }\end{array}$} \\
\hline \multicolumn{4}{|c|}{ 終着地点が調査対象駅であるバスのGPSによる盗行時間調查 } \\
\hline 調查日時 & $11($ 月 $) \sim 15($ 金 $)$ & $18($ 月) $\sim 22($ 金) & 始発〜9:30 \\
\hline 対象パス系統 & \multicolumn{3}{|c|}{ (1)ドリームハイツ発 $(17 / 5.0 \mathrm{~km})$, 汲沢団地発 $(8 / 2.1 \mathrm{~km})$} \\
\hline (バス停数/距離) & \multicolumn{3}{|c|}{ (2)聖マリアンナ発 $(21 / 6.6 \mathrm{~km})$, 新百合グリーンタウン発 $(10 / 2.7 \mathrm{~km})$} \\
\hline
\end{tabular}

間のパラメータの比較と再現精度の比較を行う。さらに, Mixed Logitモデル(以下，MXL)によって選択肢間の誤差 相関に関する考察を加える.

\section{2. データ概要}

本研究では，鉄道を利用し都心一通勤する就業者を対 象に出発時刻選択に関するアンケート調査と, 自宅から 最寄駅までのアクセス所要時間を把握するためのGPS端 末を用いたバス所要時間調查を独自に行った. 調查概要 を表 1 に示寸．調查対象地は，JR東海道線戸塚駅周辺 (以下, 戸塚), 小田急小田原線新百合ヶ丘駅周辺(以下， 新百合)である.いずれの地域も都心までの鉄道乗車時間 が30分圈内の地点にあたり，地域間比較が行い易いと考 えて選定した. ただし，小田急線の駅間距離が短いこと， またこの地域の鉄道路線の密度が高いことから，新百合 は戸塚に比べてバス利用者のアクセス時間が短くなると いう交通環境上の違いがある.

\section{（1）調査の方法と概要}

アンケート調査は，通勤者を対象に，複数のバス停留 所で午前中のバス利用者，対象駅周辺で夕刻の帰宅者に 配布した. 配布枚数は, 4934枚で, 回収率は30\%以上で あった. また, 調査票のうち出発時刻選択モデルに関連 する項目として，家を出る時刻，最寄駅までのアクセス 手段と所要時間, 鉄道の通勤経路, 会社始業時刻やフレ ックスタイム制度適用などの就業形態，個人属性を設け た.

GPSによるバス所要時間調査は，神奈川中央交通（戸 


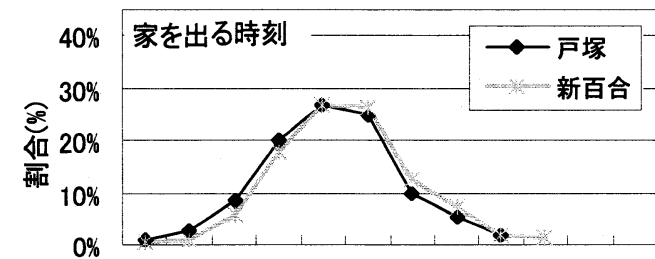

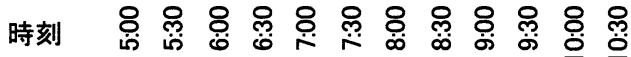

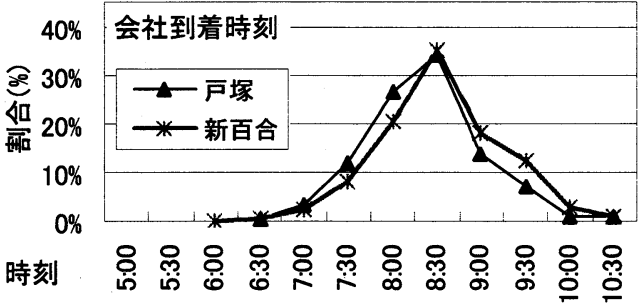

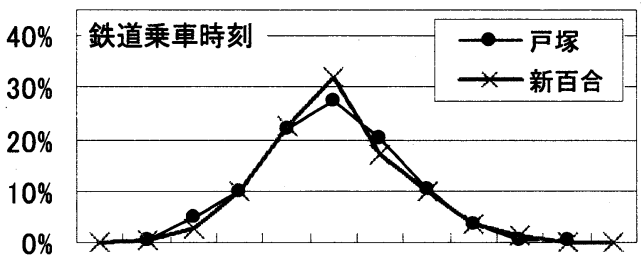

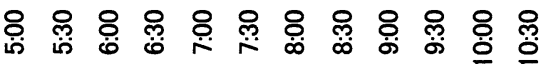

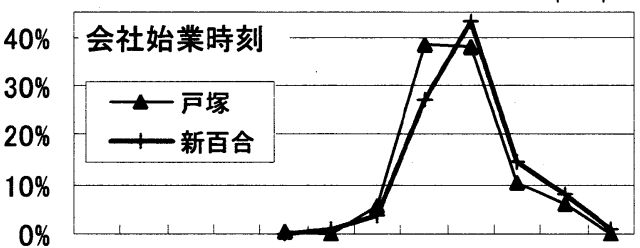

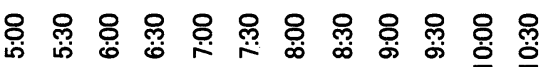

図1. 各地点の行動の時刻分布

表2. 各行動時刻の平均と分散

\begin{tabular}{c|rr|rr}
\hline & \multicolumn{2}{|c|}{ 戸塚 } & \multicolumn{2}{c}{ 新百合ヶ丘 } \\
\cline { 2 - 6 } & \multicolumn{1}{|c}{ 平均 } & 分散 & \multicolumn{1}{c}{ 平均 } & 分散 \\
\hline 家を出る時刻 & $7: 15$ & 1864.3 & $7: 24$ & 1904.4 \\
乗車時刻 & $7: 42$ & 1808.4 & $7: 43$ & 1878.5 \\
会社到着時刻 & $8: 34$ & 1537.1 & $8: 45$ & 1857.0 \\
始業時刻 & $8: 56$ & 973.0 & $9: 03$ & 1095.5 \\
\hline サンプル数 & \multicolumn{2}{|c|}{428} & \multicolumn{2}{|c}{537} \\
\hline
\end{tabular}

塚），小田急バス（新百合）に依頼して調査を行った. 対象バス系統は, 各対象駅を終着地とする系統で, 経路 が長く遅延が発生しやすい系統（戸50系 : ドリームハイ ツ発，新17系 : 聖マリアンナ発）と，比較的距離が短い 団地を始発とする利用者が多い系統 (戸53系: 汲沢団地 発，新10系 : 新百合グリーンタウン発）とした. GPS端 末のデータ取得が確実にできるように，運転台の前の空 際のスペースにGPS端末を固定した. 観測日時は，平日 5 日間で，路線ごと1日9台を用い始発〜9:39までを約 15 分 間隔で所要時間を計測できるように運行計画表をもとに バスを特定した. 座標位置データは 3 秒ピッチで取得し た.

\section{（2）通勤者の出発時刻選択行動の基礎的考察}

本調査では1534サンプルを回収したが，東京方面に向 かうサンプルを抽出し，戸塚が428サンプル，新百合が5 37サンプルの計 965 サンプルを有効データとして分析を 進める.

このサンプルの属性は, 各調查地点で男女比が7:3, 平 均年齢は45歳(戸场)，47歳(新百合)で調查地点での性年齢 属性はほぼ同じである．両地点に共通して男性が高年齢 層，女性は若年齢層に偏っている．通勤者の業務形態は,

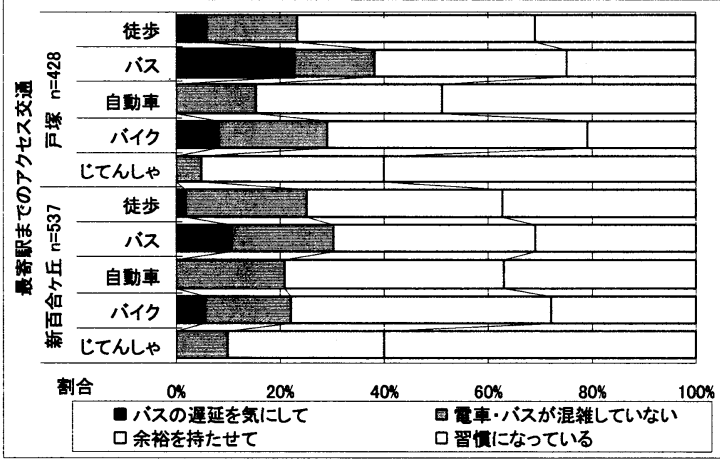

図2.アクセス交通機関別の出発時刻選択要因

定時出勤/フレックスタイム制度の割合が，戸塚は $82 \%$ $/ 14 \%$, 新百合ヶ丘は $71 \% / 18 \%$ で，定時出勤の割合が 小さい新百合の方が多様な就業形態となっている. 被験 者の就業地は, 都区内が非常に多く（特に，港·品川・千 代田·新宿・中央区に集中），戸塚では，都内-66\%・神奈 川県-32\%（横浜市-24\%・川崎市-9\%)，新百合では，都 内-90\%・川崎市-9.5\%である.

鉄道乗車時刻は，各調査地点とも7:30台に集中してい る.これは都市交通年報で報告されている最混雑時間帯 （JR東海道線，7:30 8:30川崎 $\rightarrow$ 品川間 209\%，小田急小 田原線，7:48〜8:48世田谷代田 $\rightarrow$ 下北沢間 190\%）とほぼ 一致している.

図 1 は，調査地別に，自宅出発時刻，最初の鉄道乗車 (主に戸塚駅，新百合ヶ丘駅 時刻, 会社到着時刻, 会 社始業時刻の4つを30分間隔で集計したものである. 出 発時刻から目的地到着時刻までの時間を追うにつれ分散 していた行動が集中していくことがわかる. 会社到着時 刻, 会社始業時刻において，新百合が戸塚に比一遅い時 間に偏心している理由は，フレックスタイム制度の割合 


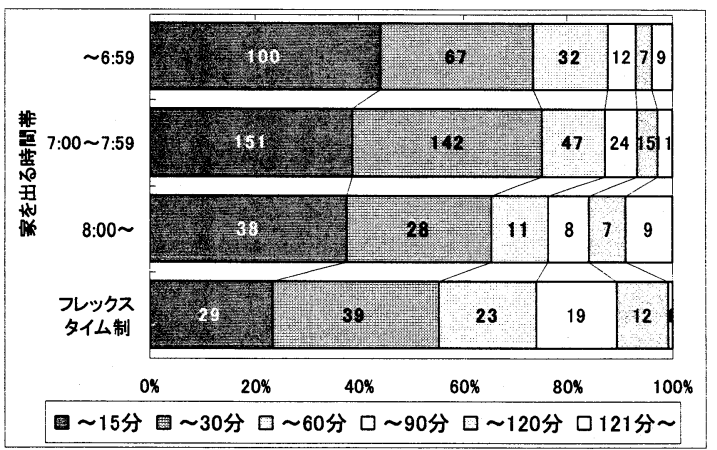

図3．定時出勤とフレックスタイム制度の出発時刻幅

表3. 選択肢設定による選択肢集合の変化

\begin{tabular}{|c|c|c|c|c|c|c|}
\hline & \multicolumn{3}{|c|}{ 户塚 } & \multicolumn{3}{|c|}{ 新百合ヶ丘 } \\
\hline & 18肢 & 9肢 & 5肢 & 18肢 & 9肢 & 5肢 \\
\hline 2肢 & $33.1 \%$ & $56.6 \%$ & $76.2 \%$ & $27.5 \%$ & $52.4 \%$ & $72.1 \%$ \\
\hline 3肢 & $22.1 \%$ & $20.6 \%$ & $16.3 \%$ & $26.1 \%$ & $21.4 \%$ & $21.4 \%$ \\
\hline 4肢 & $11.5 \%$ & $11.3 \%$ & $6.2 \%$ & $10.5 \%$ & $12.0 \%$ & $5.7 \%$ \\
\hline 5肢 & $12.0 \%$ & $5.3 \%$ & $1.3 \%$ & $10.8 \%$ & $7.5 \%$ & $0.8 \%$ \\
\hline 6肢 & $4.3 \%$ & $2.5 \%$ & & $4.5 \%$ & $3.1 \%$ & \\
\hline 7肢 & $4.5 \%$ & $2.2 \%$ & & $7.2 \%$ & $2.2 \%$ & \\
\hline 8肢 & $3.2 \%$ & $1.3 \%$ & & $2.4 \%$ & $1.1 \%$ & \\
\hline 9肢 & $3.2 \%$ & $0.3 \%$ & & $4.5 \%$ & $0.3 \%$ & \\
\hline 10肢 & $0.8 \%$ & & & $1.4 \%$ & & \\
\hline 11肢 & $2.1 \%$ & & & $1.7 \%$ & & \\
\hline 12肢 & $0.3 \%$ & & & $0.5 \%$ & & \\
\hline 13肢 & $1.6 \%$ & & & $1.2 \%$ & & \\
\hline 14肢 & $0.3 \%$ & & & $0.5 \%$ & & \\
\hline 15肢 & $0.3 \%$ & & & $0.5 \%$ & & : \\
\hline 16肢 & $0.5 \%$ & & & $0.5 \%$ & & \\
\hline 17肢 & $0.0 \%$ & & & $0.0 \%$ & & \\
\hline 18肢 & $0.3 \%$ & & & $0.2 \%$ & & \\
\hline 総計 & 375 & 320 & 227 & 418 & 359 & 262 \\
\hline
\end{tabular}

の違いによるものと考えられる. 会社始業時刻が戸塚に 比して新百合の分散が大きい理由は, 就業形態の割合の 違いによるものと考えられる.

表 2 は, 図 1 の各地点の時刻の平均と分散を示したも のである. 家を出る時刻は, 戸塚が新百合より9分早い. 家を出る時刻と乗車時刻の差は, 戸塚は27分, 新百合は 16分であることから，戸塚の通勤者はアクセス所要時間 が長い. 目的地に近づくにつれ分散が小さくなっていく ことがわかるが，家を出る時刻と鉄道乗車時刻とでは分 散の変化が少ないことから，アクセス所要時間が不確実 であることが起因していることが考えられる.

図 2 は, 最寄駅までのアクセス交通機関別に出発時刻 選択要因のうち, 多くの通勤者が答えた 4 つ要因につ いて集計したものである. 戸塚のバス利用者は，新百合 と比較して「バスの遅延を気にして」の要因が多い. 実 際のバスの遅延状況は後述する. また，「余裕を持たせ

て」，「習慣になっている」と答えている通勤者が多い.

図3は, 最も早い出発時刻と最も遅い出発時刻の差を 出発時刻の選択可能な幅として, 自宅の出発時間帯別に 集計したものである. 早く出発する人は選択幅が小さく, 遅く出るに従って出発時刻の選択幅は様々であることが 分かる. 特に, フレックスタイム制の通勤者は様々な時

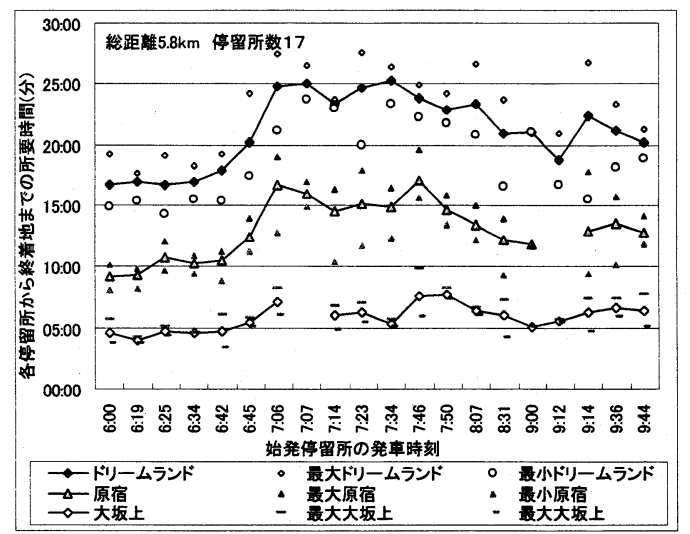

図 4. ドリームハイツ発の各停留所毎の所要時間(戸塚)

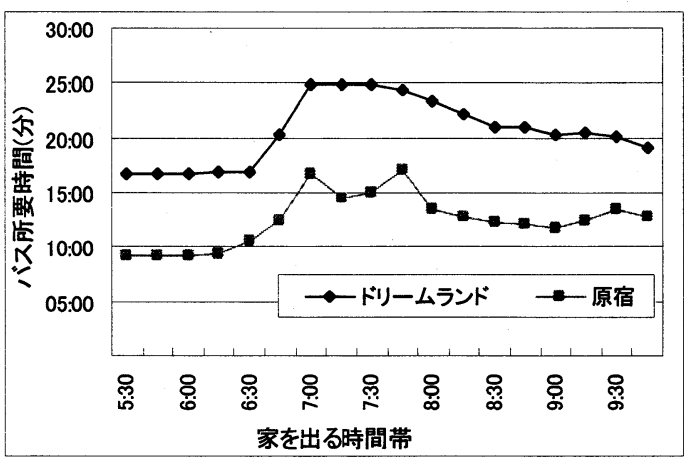

図 5. 修正後のバス所要時間(戸塚)

間幅をもっていることがわかる.

次に, バスの時刻別所要時間の変動について述べる. 図4に戸塚のドリームハイツ発(戸50系)の戸塚駅までの バス所要時間をバス停別に示す. 5 日間のデータである ため, 各時刻各バス停で最大5サンプルを取得している. 横軸がドリームハイツを出発した時間, 縦軸が各バス停 から終着地までの所要時間である. ドリームランドから 戸塚駅までの平均所要時間は6:00発では16分, 7:06では2 5分であり, 平均日変動では9分である. また，週変動は $7: 23$ 発で最大27分, 最小20分で差は7分である. これよ り特定の時間帯で週変動, 日変動が大きいことが確認で きた. 新百合の時刻別の所要時間変動は, 戸塚と比べる と小さく, 平均日変動は5分であった. これにより, 図 2 の戸塚のバス利用者が「バスの遅延を気にして」いる ことが裏付けられた.

\section{（3）出発時刻選択モデルに用いるデータ}

出発時間帯が5:30 -9:59までの被験者を対象にモデル構 築のデータ整備を行う.モデルの変数はアクセス所要時 間(分)(以下, access time), 鉄道乗車時間 $\times$ 混雑率(分·\%) (以下, congestion), 早着時間(以下, time early), 遅着時 間(以下, time late)とした. 
既往の出発時刻選択モデルには，定数項を用いないケ 一スが多い. 例えば, 家田ら 2)は, 多くのスケジュール コストの変数のみであるし，また， Chin ${ }^{7}$ やSmall ${ }^{8}$ は， 5 分ピッチの11〜12選択モデルの構築を行っている. 変数 には, 2〜4つのスケジュールコストと, 多くの属性ダミ 一とスケジュールコストを組み合わせた変数を用いてい る. 定数項や多くのダミーを用いることで，モデル精度 自体は向上すると考えられるが，研究目的の一つが，選 択肢設定区分による各パラメータの感度の相違の分析で あり，選択肢の設定によって定数項の設定が変わること， モデル構築に用いるサンプルが異なるため, サンプルに 含まれる個人属性の割合が変化することから, 複雑な変 数や定数項は用いずに出発時刻選択モデルに一般に用い られる基本的なパラメータを設定することとした.

LOSは，それぞれ以下のように設定した. まず，15分 ピッチのLOSデータの作成方法について述べる.

access timeは, バス利用者が図 4 に示したGPS調査で 計測した15分ピッチの平均所要時間を用いた. GPSデー 夕は，5日間調查の各停留所で最大5サンプルを取得して いるが，欠損データが存在すると，隣り合う時間帯で所 要時間変動が非常に大きく異なる. この問題に対処する ために平均的な時間を取るように平滑化を行った，平滑 処理を行った後のバス所要時間分布を図 5 に示す. なお, バス以外のアクセス交通機関（徒歩を含む）の利用者に は，アンケートに記述された所要時間を用い時間帯によ る変動は設定していない.

congestionは，駅間の乗車時間に駅間混雑率（断面交通 量六輸送力）を乗じたものである. 通勤者の利用経路に 基づき, 時刻表（東京時刻表2002年11月, 弘済出版社) によって出発時刻を始発 $9: 59$ までの15分ごとに駅間所要 時間と輸送力(列車本数と車輛編成数)を作成した. 混雑 率は平成12年大都市交通センサスデータから15分ピッチ の駅間断面交通量を用いて駅間混雑率データを作成した. 乗換時間は全データ同一に5分と設定した.

time early, time lateについては, 通勤者の会社到着時 刻と会社始業時刻を元に作成した.

選択肢の設定を30分ピッチ，60分ピッチとした場合の LOSは，その時間帯に当たる15分間隔のLOSを平均して 設定した. 選択肢設定によって異なるサンプルレートを 表 3 に示す．離散選択モデルであるため2肢以上選択す るサンプルでモデル推定を行う．18肢は15分間隔で30分 以上の出発時刻幅があるサンプルとなる. 9肢は30分間 隔，5肢は60分間隔であり，9肢では半数の選択肢集合が， 5支では大半のサンプルがバイナリーの選択肢集合とな っている.

\section{3. 選択肢区分による出発時刻選択モデルの比較}

\section{（1）選択肢区分による出発時刻選択モデルの推定}

表 4 に出発時刻選択モデルの推定結果を示す. 戸塚と 新百合データをプーリングしたモデル「統合（戸塚+新 百合）」と，地域差を把握するための「戸塚」と「新百 合」のモデルを推定した. 15分ピッチの18肢, 30分ピッ チの9肢，60分ピッチの5肢選択でそれぞれ多項ロジット モデル（以下，MNL）とMXLを推定し18種類のモデル を構築した. なお，MXLでは隣り合う選択肢間の誤差相 関に関わるパラメータsを推定した.

time early, time lateの2変数はいずれのモデルも1\%有 意である. congestionも概ね有意で, access time以外の符 号条件は成立している.

\section{（2）モデルの精度に関する考察}

モデル全体の精度を示す尤度比は，選択肢数が少なけ れば，また変数が多いMXLのほうが上昇するのは当然の ことであるので, 相関係数, 平均残差, 期待値, 最終尤 度を指標にしてモデルの精度を検証する．表 5 に各指標 に基づいて計算されたモデル精度の比較表を示す.3種 類の選択肢設定のデータセットに対して3種類のモデル パラメータがどの程度の再現性をもつかを確認するため の表となっている.

まず，データセットの作成方法と各精度指標の算出方 法について説明する．18肢，9肢，5肢のモデル構築に用 いたサンプルを抽出し，そのサンプルの選択結果，選択 肢集合およひLOSをそれぞれ15分ピッチ，30分ピッチ， 60分ピッチのデータに変換し, 計9種類のデータセット を作成した. 例えば, データセット18でモデル18の場合 は15分ピッチのデータをそのまま利用するが，データセ ット18でモデル9の場合は，18肢モデルの構築に用いた サンプルの15分ピッチの選択結果，選択肢集合および OSを30分ピッチに集約したデータセットで，9肢モデル を用いて選択確率を推計し，モデル精度の指標を算出す る. 同様に, データセット18でモデル5の場合は, 15 分 ピッチのデータを60分ピッチに集約し，5肢モデルを用 いてモデル精度の指標を算出する. データセット9でモ デル5の場合も同様の方法をとった.

なお，最終尤度を計算する際に，選択肢集合の集約に よって選択可能性が1つとなるサンプルが発生するが， その場合の選択確率は，18肢から9肢，9肢加ら5肢の場 合は選択確率を $1 / 2$ と与え，18肢から 5 肢の場合は選択確 率を $1 / 4$ と与えた. このような処理を行った最終尤度の指 標であることに留意する必要がある.

一方, データセット9でモデル18の場合は，18肢モデ ルの構築に用いたサンプルの選択結果，選択肢集合およ びOS から9肢モデルの構築に用いたサンプルを抽出し たデータセットを用いる. 18肢モデルで選択確率を推計 してモデル精度の指標を算出する. なお, サンプルの選 
表4. パラメータの推定結果

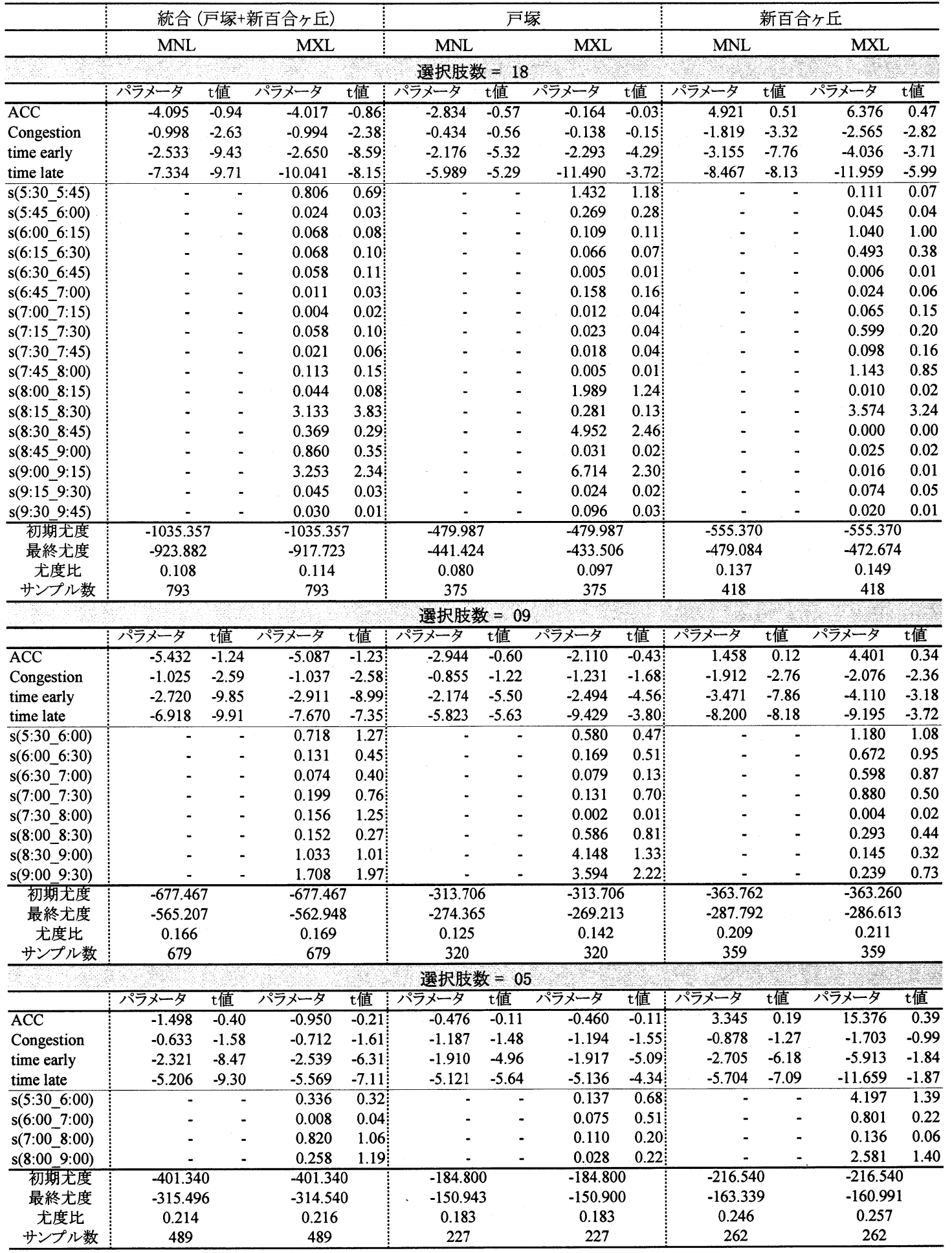


表 5. 選択肢区分によるモデルの精度の比較

\begin{tabular}{|c|c|c|c|c|c|c|c|c|c|c|c|c|c|}
\hline \multirow{2}{*}{ データセット } & \multirow[b]{2}{*}{ モデル } & \multicolumn{4}{|c|}{ 統合(戸塚＋新百合ヶ丘) } & \multicolumn{4}{|c|}{ 戸塚 } & \multicolumn{4}{|c|}{ 新百合ヶ丘 } \\
\hline & & 相関係数 & 平均残差 & 期待值 & 最終尤度 & 相関係数 & 平均残差 & 期待値 & 最終尤度 & 相関係数 & 平均残差 & 期待值 & 最終尤度 \\
\hline \multirow{3}{*}{18} & 18 & 0.938 & 14.5 & $7: 25$ & -923.9 & 0.933 & 15.5 & $7: 18$ & -441.5 & 0.942 & 13.6 & $7: 29$ & -479.1 \\
\hline & 9 & 0.929 & 15.6 & $7: 26$ & -644.9 & 0.927 & 16.4 & $7: 21$ & -312.6 & 0.930 & 14.9 & $7: 30$ & -329.3 \\
\hline & 5 & 0.899 & 17.9 & $7: 23$ & -746.6 & 0.902 & 18.2 & $7: 19$ & -357.8 & 0.894 & 17.7 & $7: 27$ & -387.8 \\
\hline \multicolumn{2}{|c|}{ サンプル数/真の期待值 } & \multicolumn{4}{|c|}{$793 / 7: 21$} & \multicolumn{4}{|c|}{$375 / 7: 15$} & \multicolumn{4}{|c|}{$418 / 7: 26$} \\
\hline \multirow{3}{*}{9} & 18 & 0.917 & 17.3 & $7: 27$ & -568.4 & 0.912 & 18.4 & $7: 24$ & -275.7 & 0.920 & 16.2 & $7: 31$ & -289.6 \\
\hline & 9 & 0.918 & 16.9 & $7: 27$ & -565.2 & 0.914 & 17.9 & $7: 23$ & -274.4 & 0.921 & 16.0 & $7: 31$ & -287.8 \\
\hline & 5 & 0.897 & 18.1 & $7: 24$ & -453.3 & 0.899 & 18.5 & $7: 21$ & -216.6 & 0.894 & 17.8 & $7: 28$ & -236.5 \\
\hline \multicolumn{2}{|c|}{ サンプル数/真の期待值 } & \multicolumn{4}{|c|}{$679 / 7: 22$} & \multicolumn{4}{|c|}{$320 / 7: 18$} & \multicolumn{4}{|c|}{$359 / 7: 26$} \\
\hline \multirow{3}{*}{5} & 18 & 0.911 & 17.4 & $7: 29$ & -285.2 & 0.904 & 18.7 & $7: 26$ & -137.2 & 0.915 & 16.2 & $7: 32$ & $\overline{-146.4}$ \\
\hline & 9 & 0.875 & 21.0 & $7: 29$ & -318.8 & 0.879 & 22.4 & $7: 27$ & -153.2 & 0.873 & 19.7 & $7: 32$ & -163.3 \\
\hline & 5 & 0.881 & 20.1 & 7:27 & -315.5 & 0.885 & 20.9 & $7: 24$ & -150.9 & 0.876 & 19.4 & $7: 30$ & -163.3 \\
\hline \multicolumn{2}{|c|}{ サンプル数/真の期待值 } & \multicolumn{4}{|c|}{$489 / 7: 23$} & \multicolumn{4}{|c|}{$227 / 7: 19$} & \multicolumn{4}{|c|}{$262 / 7: 26$} \\
\hline
\end{tabular}

表6. 選択肢区分によるLOS の最大値と最小値の差

\begin{tabular}{|c|c|c|c|c|c|c|c|}
\hline \multirow{2}{*}{\multicolumn{2}{|c|}{ 最大値と最小值の差 }} & \multicolumn{3}{|c|}{ 戸塚 } & \multicolumn{3}{|c|}{ 新百合ヶ丘 } \\
\hline & & 18肢 & 9肢 & 5肢 & 18肢 & 9肢 & 5肢 \\
\hline \multirow{3}{*}{$\begin{array}{l}\text { access time } \\
\text { (min) } \\
\text { (busのみ) }\end{array}$} & 平均值 & 3.16 & 3.33 & 4.20 & 2.02 & 1.82 & 1.42 \\
\hline & 最頻値 & 0.70 & 1.80 & 6.90 & 2.00 & 1.30 & 1.60 \\
\hline & 標準偏差 & 2.54 & 2.41 & 2.37 & 1.62 & 1.32 & 0.55 \\
\hline \multirow{3}{*}{$\begin{array}{c}\text { congestion } \\
(\min \bullet \%)\end{array}$} & 平均值 & 19.02 & 21.56 & 24.38 & 28.10 & 27.89 & 31.89 \\
\hline & 最頻値 & 4.68 & 3.87 & 9.21 & 1.16 & 21.88 & 23.76 \\
\hline & 標準偏差 & 18.29 & 17.65 & 16.72 & 21.74 & 18.40 & 14.67 \\
\hline \multirow{3}{*}{$\begin{array}{l}\text { time early } \\
\text { (min) }\end{array}$} & 平均值 & 37.38 & 41.66 & 51.82 & 35.89 & 39.58 & 48.94 \\
\hline & 最頻值 & 15.00 & 30.00 & 45.00 & 15.00 & 30.00 & 38.00 \\
\hline & 標準偏差 & 29.98 & 27.48 & 26.71 & 29.02 & 26.76 & 24.53 \\
\hline \multirow{3}{*}{$\begin{array}{r}\text { time late } \\
\text { (min) }\end{array}$} & 平均值 & 11.72 & 16.44 & 27.01 & 16.44 & 21.62 & 33.23 \\
\hline & 最頻値 & 0.00 & 0.00 & 23.00 & 0.00 & 0.00 & 11.00 \\
\hline & 標準偏差 & 25.80 & 27.96 & 29.81 & 28.20 & 30.39 & 32.29 \\
\hline サン & & 375 & 320 & 227 & 418 & 359 & 262 \\
\hline
\end{tabular}

択結果は30分ピッチであるのに対して，モデルは15分ピ ッチで選択確率が推計されるので，分割された2つの選 択肢の選択確率を合算した. データセット5でモデル18 の場合は4つの選択肢の選択確率を合算した. データセ ット5でモデル9の場合も 2 つ選択肢の選択確率を合算 した.

相関係数は，実データ（回答された出発時刻）とモデ ルより推定された期待值との相関である. 期待値は, 各 選択肢の選択確率と各選択肢の中央値時刻との積和によ り算出される. 平均残差は，実データと期待值との差分 の二乗和から得られる分散を, サンプル数で割り平方根 をとっている. 最終尤度は, 選択確率の対数をとった值 の総和で得られる.

相関係数と平均残差については，データセットとモデ ルセットの選択肢が大きいほど精度が向上する傾向にあ り, 統合18肢データセットの5肢モデルから18肢モデル の相関係数は0.899から0.938 几上昇し，平均残差は17.9分 から14.5分と小さくなっている.

期待值を真の期待値（実データより算出）と比較する と，データセット内のモデル選択肢を集約（5肢）した ほうが約2 3分の差ではあるが，真の期待值に近いよう に見える. しかし，全体的に比較すると18肢データセッ トの期待值が真の期待値に近い結果となっている. これ

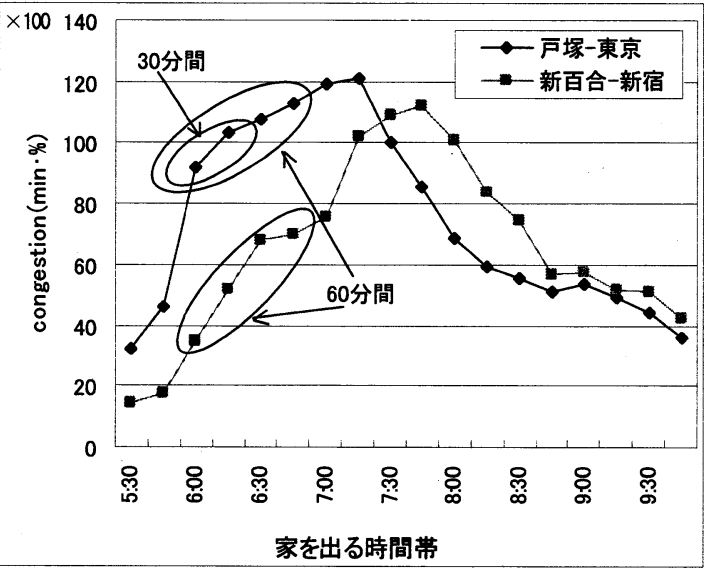

図6. 時間带別のLOS の変化

は18肢データセットの場合の期待值が，15分ピッチでの 中央值時刻で算出しているため, 真の期待値との乘離が 少ないことを表している. よって，モデル選択肢の60分 ピッチ中央值時刻を代表值時刻としている5肢が真の期 待値と近くなる傾向は偶然の結果と考える.

最終尤度は，選択肢区分が1ランク粗くなると大きく なった。これは，先に述べたように選択肢の集約によっ て選択肢集合が1つとなってしまうサンプルの選択確率 を $1 / 2$ もくは $1 / 4$ と設定していることが原因と考えられ る. 例えば，統合デー夕において18肢から9肢にする場 合，選択確率を 0.5 としたサンプルの割合は $14 \% ， 18$ 肢か ら5肢にしたときは選択確率を 0.25 としたサンプル割合は 39\%である. 表 3に示したように，選択肢集合は，選択 肢数が少ないサンプルが多く，選択肢数が多くなるにつ れてサンプルは少なくなる. このような選択肢集合の変 化をも含めて精度を評価するためには，筆者らが以前に 構築した選択肢集合の選別モデルりを併せて推計する必 要があると考える.

\section{（3）パラメータの感度に関する考察}

選択肢ごとの各変数のパラメータ感度についてみると, オーダーに大きな差はないことが分かる. 特に，18肢モ デルと9肢モデルでは大きな差がない，18肢と9肢のパラ 
メータ間で $\mathrm{t}$ 検定を行った結果，有意水準 $5 \%$ 差がな い結果となった. 9肢と5肢のパラメータ間では有意水準 10\%でtime lateに差があったが，他のパラメータに差は 見られない．5肢選択は，18肢，9肢に比べてパラメータ の感度が多少低下している. 特にtime early, time lateの2 つの変数については感度が低くなる傾向にある.

そこで, 表6に示すように, 各サンプルのLOSの最大 值と最小值との差の平均値, 最頻值, 標準偏差を比較す る.ここではaccess time (バスのみ) の戸塚18肢のデー タセットは, 平均值が3.16分で標準偏差は2.54である. それと比較して, time earlyは平均值37.38分, 標準偏差2 9.98で, time lateではtime earlyと同様に大きな值をとっ ている. また，18肢より5肢のほうがLOSの差は大きい ことがわかる. この理由を, 図6に示したcongestionの時 刻別のLOSで考えると，15分ピッチの18肢のとき選択肢 数が2〜4の場合, LOSに差がない下での選択行動である ため, 感度が大きく推定される. 逆に5肢の場合は，1時 間平均值のLOSとなり，さらに，18肢選択の2３選択肢 のサンプルはカットされるため, 選択肢間のLOSの差が 大きくなり，感度が小さく推定されると考えられえる.

戸塚モデルでは, congestionが18肢において有意となら ないが，5肢ではLOSの差が大きくなるため，推定され たパラメータが有意となる. これは, 選択肢集合内での 混雑率が被験者に認知できる程の差がないため, 混雑を 回避する行動をとっていないためと考えられる.

\section{（4）選択肢間の誤差相関に関する考察}

MXLでは，隣り合う選択肢間ごとに誤差相関を表すパ ラメータsを推定した. 18肢の統合, 戸塚, 新百合デー タでは, ピークを過ぎた8:00〜 9:00において誤差相関が 見られた.この理由として，8:00以降の時間帯の通勤者 はフレックスタイム制度が多く選択幅が大きいことが図 3 で確認されている. この時間帯の通勤者は, 効用の高 い時間帯に必ずしも出発していない傾向があることも一 因ではないかと考えられる。

9肢ではs(9:00_9:30)に相関が見られるものの，5肢では 選択肢間に相関は見られない. 30分ピッチ，60分ピッチ の選択肢設定であれば，選択肢間の誤差相関に神経質に ならなくても良いことが確認された。

\section{4. おわりに}

本研究では，選択肢の設定の違いによるモデルの精度 とパラメータ感度の分析, そして, 選択肢間の誤差相関 の確認を行った.この分析結果から, 選択肢区分の細か さとモデルの精度は必ずしも相反しないこと, パラメー タの感度はLOSの最大值と最小值の差と密接に関係して いることが明らかとなった. 3種のモデルでは，推定結
果, 相関係数, 期待值から判断して，15分間隔のモデル が望ましいと考える. 但し, オフピーク時間帯で誤差相 関が生じる可能性がある. この原因の 1 つして, オフ ピーク時間帯では一部の時刻の選択結果の数が極端に少 なくなることも理由として挙げられる. よってサンプル 数を十分に取ることが必要である. また, LOS(特に鉄道 の混雑率や乗車時間)の精度を高めることが必要である.

9肢選択のMNLは，18肢と比較してパラメータ感度が 大きく劣化しないこと, モデルの精度の劣化も小さいこ と，IAの問題に神経質にならなくて良いことなど実用 上のメリットは大きいと考える.

\section{謝 辞}

Mixed Logit モデル推定にはカリフォルニア大学Berkel ey校のTrain教授作成のプログラムを使用した. バス所要 時間調查については神奈川中央交通（株），小田急バス

（株）の協力を得た. また，平成12年大都市交通センサ スによる断面交通量の推計は（株）ライテックに協力を 得た．ここに記して謝意を表する．最後に，本論文投稿 するにあたり幾つかの問題点を的確に指摘いただいた査 読者にも謝意を表したい.

\section{参考文献}

1)原田知可子.岩倉成志·森地茂[2002]都市鉄道の時刻別 需要予測手法に関する研究, 土木計画学研究·講演集, $\mathrm{N}$ 026, CD-ROM

2)家田仁·土谷和之・ファンレ ビン・岡村敏之[2002]大都 市圈鉄道需要の時刻集中特性予測モデルの構築と首都圈 鉄道ネットワークへの適用, 土木学会論文集, No702, IV-55, pp65-79

3)Yai.T,T.Shimizu[1998]:Multinomial Probit with Structured Covariance for Choice Situations with Similar Alternatives, Transportation. Research Record 1645,pp.69-75

4)藤原章正-神田祐亮·杉恵頼寧·岡村敏之[2000]時刻選択 モデルの選択肢区分が選択肢の類似性及び不均一性に及 ぼす影響, 土木計画学研究·論文集, No17, pp599-604 5)兵藤哲朗・章翔[2000]Mixed Logitモデルの汎用性に着 目した特性分析，土木学会論文集，No.660,pp.89-99 6)財団法人運輸政策研究機構[2002]平成13年版都市交通 年報

7)T.H.Chin[1990]:Influence on commuter trip departure time decisions in Singapore,Transpn Res.-A ,Vol.24,NO.5,pp321333

8) Kenneth A. Small[1982]:The Scheduling of Consumer A ctivities: Work Trip,The American Economic Review,Vol.72, No.3,pp467-479 
都市鉄道利用者を対象とした出発時刻選択モデルの選択肢設定に関する基礎的考察*

岩倉成志 $* *$ ・原田知可子***·鈴木修司****

本研究は，東海道線戸塚駅，小田急小田原線新百合ヶ丘駅を利用する都市鉄道通勤者の出発時刻選択モデルを構築し， 出発時刻の選択肢区分の設定を変更した場合のモデルの再現精度, パラメータ感度の変化，誤差相関に関する実証分析 を試みた.この結果，選択肢区分の細かさとモデルの精度は必ずしも相反しないことが明らかとなった．モデル精度や 表現力からみれば15分ピッチのモデルが推奨される. ただし，選択肢間の誤差相関が生じるといった問題がある. 30分 ピッチのモデルであれば, 15 分ピッチに比較してパラメータ感度が大きく劣化しないこと，モデルの精度の劣化も小さ いこと，IIAの問題に神経質にならなくて良いことなど実用上のメリットは大きいと考える.

Comparative analysis of choice set for commuting time of day choice model in urban railway networks* By Seiji IWAKURA** • Chikako HARADA*** • Shuuji SUZUKI****

We examine basic analysis on the choice set classification of discrete choice model for departure time decisions in urban rai lway network. This paper is to analyze departure time decisions factor on morning commuter such as access time variance, co ngestion ratio and work start time. The estimated time of day models are compared on the basis of model accuracy, parameter sensitivity and error correlation among alternatives. 